\title{
DEVELOPMENT OF PROBLEM SOLVING-ORIENTED WORKSHEET OF PHYSICS LEARNING IN SENIOR HIGH SCHOOL
}

\author{
Muhammad Syahrul Kahar*1, Ismail Suardi Wekke², Muhamad Ruslan Layn ${ }^{3}$ \\ ${ }^{1,3}$ Mathematics Education Department, Universitas Muhammadiyah Sorong, Papua, Indonesia \\ ${ }^{2}$ State Islamic College of Sorong, Papua, Indonesia \\ *Corresponding address: muhammadsyahrulkahar@gmail.com
}

Received: July $2^{\text {nd }}, 2018$. Accepted: October $20^{\text {th }}, 2018$. Published: October $28^{\text {th }}, 2018$

\begin{abstract}
This study aimed at identifying how did the improvement in the problem-solving ability of learners work in improving the ability of learners in constructing the materials obtained after the development of Learner's Worksheet in classroom learning. This research used Research and Development $(R \& D)$ approach using the Kemp model. Data collections were done through problem-solving tests, validation analysis, and correlation test. The indicators of this study included the effectiveness of the developed learner's worksheet and the increased ability of problem-solving that was seen from the learning results obtained. The results showed that the average increase in the learning outcomes of the learners was equal to 79.44 with a difference in the scores of learning outcomes where $t_{\text {count }}=32.806>$ $t_{\text {table }}=1.734$, with a significance level of 0.000. Also, the improvement of learning outcomes on the response of learners gives significant influence with a score of 0.338 with a significance level of 0.085 . Based on these results the development, the problem-solving oriented students' worksheet is declared valid and effective based on the results of validation tests by experts and the results of the implementation of classroom learning. These results impact the students' learning outcomes. It is expected that in the learning process with different materials, the worksheet can be applied in improving students' ability to solve problems. It is suggested for a research to collaborate the worksheet with other models and, media that can be linked to the problem-solving aspects, so that in its implementation, students have the confidence to succeed, be more active, and interested in problem-solving given.
\end{abstract}

(C) 2018 Physics Education, UIN Raden Intan, Lampung, Indonesia.

Keywords: learner's worksheet, learning of physics, problem-solving

\section{INTRODUCTION}

Physics learning is a subject that requires quite a lot of relatively high intellectualize so that most learners have difficulty in learning. They assume that physics learning is a fairly difficult lesson because it requires not only mathematical calculation but also the understanding of concepts (Keller et al., 2017). Therefore, the researchers apply problem solvingoriented learning model.

Some research results in various countries such as Sweden and Japan show that the average implementation of learning that has been carried out is not directed to the students' critical thinking and the ability to solve problems. This is evidenced by the students' inability to connect material taught with the phenomena that exist in their environment. The students' competence in the material provided has not been maximally achieved. Also, another thing that is very influential is the use of strategies in implementing learning tois make students active without losing focus on the material provided. These results are also consistent with reports from the two countries which explain that students whose teachers often use a variety of approaches or strategies have a higher level of achievement on problem-solving compared to teachers who only explain in 
conventional ways (Asami-Johansson, 2015).

Based on the elaboration of the findings in the two countries, Indonesia is facing similar problems. It can be seen at the research site that in the implementation of learning in schools, the teacher only implements learning by explaining the material without carrying out the collaboration of various learning strategies and media, thus impacting the competencies possessed by students. The matter gives a change in mindset for students towards the willingness and interest in participating in the lesson.

In overcoming the problems that exist in the classroom, there needs to be an implementation of learning that is oriented towards problem-solving. The ability to solve problems within certain limits can be established through the field of study and the disciplines. The issue of how to teach 'problem solving' will never be overcome without considering the type of problem to be solved, suggestions and forms of the program prepared, and a student's innate variables. Similarly (Ceberio \& Franco, 2016) explained that the problem solving oriented learning process could improve the ability of students to make hypotheses and analyze the results of the practice found.

Problem-solving strategies, in principle, use real-world problems as a context for learners to learn about critical thinking and problem solving and to acquire essential knowledge and concepts from the subject they learn. Darma (2018) states that in carrying out a learning using problem solving-oriented learning model that directs the learning outcomes on problem-solving abilities, it is possible for students to be able to describe information in accordance with their abilities and skills in processing the information obtained.

In according to (Purnamawati, Ertikanto, \& Suyatna, 2017) stated that the process of learning with the teacher is a series of reciprocity between student activities and teaching activities. In order for the learner's learning process to be effective, the teacher must act as a facilitator that provides an environment for the learning process to take place effectively and efficiently. To be a good facilitator, the teacher must master the concepts and principles of the learning process. While (Fathurrahman et al., 2018) and (Kahar, 2017) stated that in physics learning activities, teachers rarely train learners with skills. Practical activities are also rarely done on the grounds of limited time to learn conceptually and inadequacy of laboratory facilities and infrastructure, so the potential ability of learners is less trained.

When the development of learners' potency, especially their creativity of thinking during learning, is not optimal, it will result in learning that is not optimal as well. Therefore, a real effort is needed, one of which is to improve the learning process that occurs in the classroom through the use of different learning models and approaches. Thus, it needs a strategy that includes aspects of the development and implementation of tools or learning media to improve interest in learning and increase its outcomes (Kahar, 2018).

This strategy and development show students that every subject of physics is necessarily a way of thinking they must understand, not just by letting them learn from the teacher or the book, but the teacher must provide for them an opportunity to apply the knowledge they have in the real world. One of the learning tools developed is the learner's worksheet which supports to develop the strategy of problem solving-oriented learning. Similarly (Rahayu et al., 2017) explained that the implementation of students worksheet in learning oriented to various learning methods could improve some aspects of students' abilities such as 
learning motivation, and classroom learning activities.

This is in line with (Kahar et al., 2018) which explained that a learning approach using a worksheet could construct learners' understanding. The construction of the worksheet development is classified into five stages including clarification of issues, opinion disclosure, evaluation and selection, implementation, and creative performance. (Noor et al., 2017) Also stated that the development of learning tools could show the improvement of the ability of learners determined by the ability to think, especially to solve the problems of life they face. Furthermore (Powell et al., 2017) stated that the use of learning media could provide cognitive implications for students in improving problem-solving abilities.

This problem solving-oriented learning strategy can be a good solution for learners in dealing with physics lessons. The use of a model or method of learning by the characteristics of the material taught allows teachers to communicate well with learners and add their insight thinking, so they can learn the whole concept well (Fitriah, 2013). Similarly, (Tanti et al., 2017) expressed that the use of various models of learning that focus on the formation of models and media in physics learning through contextual problem solving can provide opportunities for learners to actively engage in problem-solving, and can assist them in developing learning media and other media related to the subject of physics.

One of the models and learning approaches that can make learners become more active and grow their metacognition skill, learning think mathematically, and interest in learning is by using the Problem Solving model (Schoenfeld, 2016). Similarly (Putri et al., 2017) stated that the development of learning-oriented critical thinking skills could improve the ability of students in problem-solving for the material being taught and the implementation of these learning runs effectively and efficiently.

This allows the learners to follow physics learning more contextually, can apply the concept well, to absorb learning carefully (Kahar, 2018). Also, the learning process that uses worksheets can provide more contextual learning related to the daily lives. The implementation is expected to be able to have an impact on students in improving their learning outcomes (Barniol \& Zavala, 2016)

The development is also focused on the subject of fluid that can support more dominant discussion about materials related to the learners' daily life. Firdaus \& Wilujeng (2018) explain that the development of inquiry-oriented worksheets was able to improve the students' ability and also able to improve students' critical thinking skills in solving the given questions. This can also have an impact on the learning activities carried out by students during learning.

Based on the above description, it is not appropriate to teach the subject of fluid or other materials that were collaborated into applicative aspects of learning solely by lecturing methods in the classroom. It should be taught by inviting learners to observe what they will learn and understand why the material is essential to them. Therefore, the purpose of this study was to evaluate how does the improvement of the problem-solving ability of the learners work after the development of the problem solvingoriented worksheet. In according to (English, Hudson, \& Dawes, 2013) stated that the problem-solving process was able to construct students' skills in collaborating with the context of knowledge that was obtained.

Based on the results of the research stated above, the implementation and development of a learning media by applying an approach can provide significant results in improving learning 
outcomes. Still, based on the previously mentioned research, there has not been any development of worksheets that are oriented to the students' ability to solve problems. Therefore, the researcher intends to develop a worksheet that is problem-solving oriented because in physics learning, especially in the fluid material, it is possible to stimulate the students to solve every problem stated in the worksheet.

Therefore, the achievement of the above-mentioned research objectives, students are expected to be able to identify models, methods, and strategies that were applied in every classroom learning, in order to improve their achievement and learning outcomes during the learning process. Also, they are also able to understand better the material obtained with the help of models, methods or tools in the form of learner's worksheet applied in learning.

\section{METHOD}

The research method employed is research and development (R \& D), where the design of research and development of learners' worksheet was done by referring to the development of the Kemp model. This development model consisted of several stages are (1) identification of learning problems, (2) material analysis, (3) analysis of specific learning objectives, (4) designing learning strategies, (5) establishing learning methods, and (6) developing evaluation instruments (Kemp, 1995). The revision stage can be done based on advice's given as stated in figure 1 .

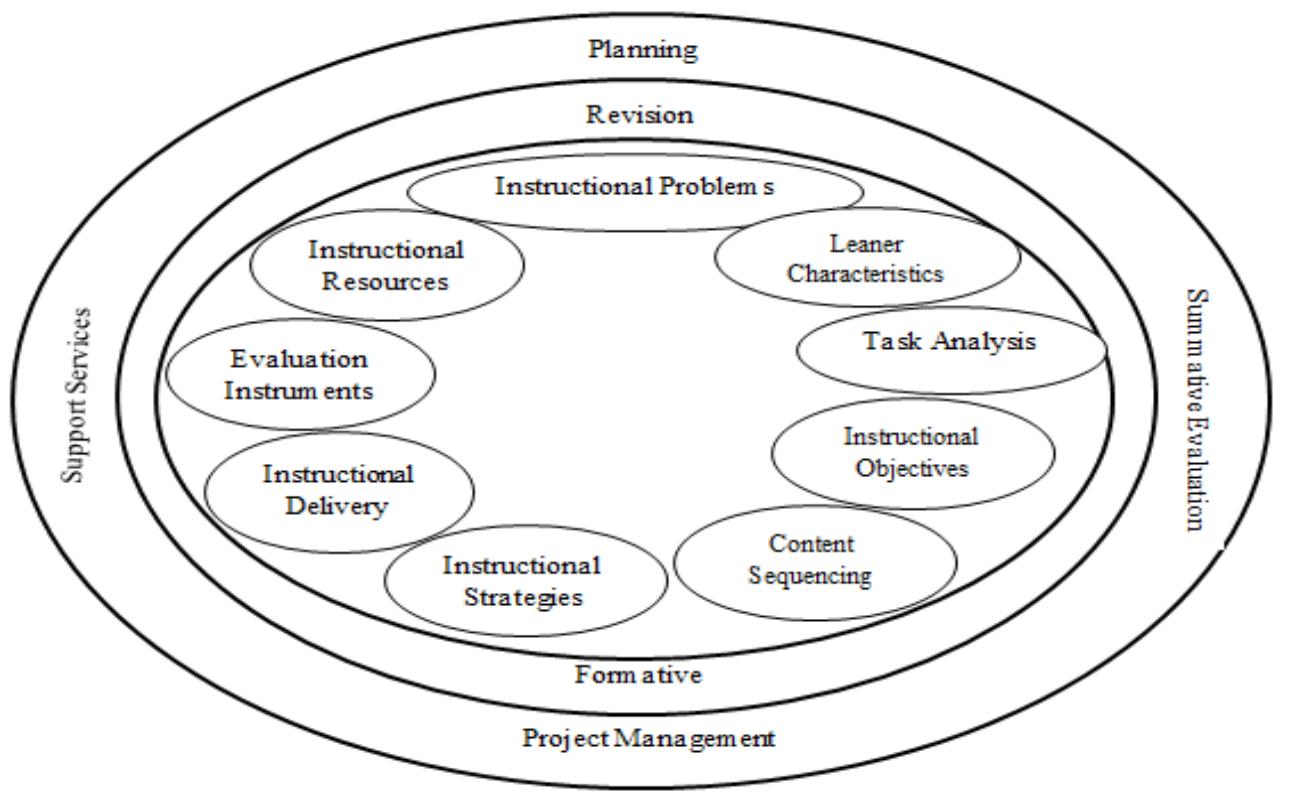

Figure 1. The cycle of development of the kemp learning model worksheet

This research was conducted at SMA Muhammadiyah Al-Amin, Sorong. The sample was 18 students of the second semester of the eleventh grade of Class XI MIA. The number of the samples was quite small since the overall students of the school were also limited.

The instruments used to collect the data in this study were the expert validation sheet and the problem-solving test. The expert validated the developed worksheet. The results of the validation can be in the form of suggestions and opinions which then be used to revise the worksheet. There were two validators consisted of lecturers and practitioners (teacher). The instruments used to collect data are as follows: 


\section{Expert Validation}

Expert validation was used by the team of validators to validate worksheets and research instruments that had been designed. The result of this validation was in the form of validators' suggestions and opinions were used to revise such devices and instruments.

\section{Problem-solving test}

To identify the achievement of the physics learning of learners, they were given a multiple-choice test. This multiple-choice test consisted of 20 items that were used after the research to the same class (Suharsimi, 2006). It was intended to identify the achievement of the problem-solving skills of learners by referring to their physics learning outcomes after being taught using a problem-solving worksheet. Also, the achievement of learning they obtained, once collaborated on their responses, was analyzed using a correlation test.

To analyze data of the development of problem solving-oriented worksheet, descriptive statistical analysis technique was used. The data analyzed were:

\section{Data analysis based on experts' validation}

Data that had been validated by experts were analyzed by considering their inputs, comments, and suggestions. The results of the analysis were presented as guidelines for revising the worksheet used in the study.

Activities carried out in the process of analyzing the validity were by finding the total mean of the mean of $(\bar{X})$ for all aspects using the formula of

$$
\bar{X}=\frac{\sum_{j=i}^{n} \bar{A}_{i}}{n},
$$

Information:

$$
\begin{array}{ll}
\bar{X} & =\text { total mean of all aspects } \\
\bar{A}_{i} & =\text { mean of the } \mathrm{i}^{\text {th }} \text { aspect } \\
\mathrm{n} & =\text { amount of aspects }
\end{array}
$$

Furthermore, the total mean $(\bar{X})$ was assessed based on the interval rate determined as follows:

$$
\begin{aligned}
& 3.5<M \leq 4 \text { Very valid } \\
& 2.5<M \leq 3.5 \text { Valid } \\
& 1.5<M \leq 2.5 \text { Quite valid } \\
& M \leq 1.5 \text { Not valid }
\end{aligned}
$$

The criteria used to decide that the learner's worksheet had a sufficient degree of validity were, among others, the mean value of validity for the overall aspects was at least being in a valid category. Otherwise, a revision was necessary to do based on the suggestion of the validators or by reviewing the aspects that were considered to be lacking.

\section{RESULTS AND DISCUSSION}

The results of the research are (1) Analysis of expert test on the learner's worksheet; and (2) Field test analysis.

The initial product developed is a learner's worksheet (Figure 1) in physics learning at SMA Muhammadiyah AlAmin. Before trial, it is necessary to validate by experts by the field of research to validate the resulting product. Validation is done by providing an initial draft of the learner's worksheet with an evaluation sheet for each physics expert and teacher. An evaluation sheet is a questionnaire that contains aspects of assessment and quality, suggestions, and comments from experts and teachers of physics of SMA Muhammadiyah AlAmin about the worksheet. The results of the evaluation are in the form of values of the aspect of the quality of the learning worksheet by using scale 1 to 4 .

This developed worksheet has received feedback from some experts so that it can be more qualified and achieve the expected goals. The assessment developed includes four main elements.

The four elements include Format, Content, Language, and Benefits/ Usability. The experts in the assessment of the worksheet developed are (1) 
Rahmatullah Bin Arsyad, S.Pd., M. Pd (Lecturer of Muhammadiyah University of Sorong) and (2) Nurlia Malawat, S. Si (Physics Teacher). The data presented are the result of the experts' assessment of the worksheet product that was developed. The results so vary according to the assessors. The assessment presented in order to see how far the quality of the product was developed. Firstly, the format shows that the mean score obtained is 3.75. When viewed from the rating category described in the previous section, then the mean score is included in the category of 'Very Good.' Secondly, the content shows that the mean score earned is 3.5 then the mean score is considered as 'Very Good.' Thirdly, Language shows that the mean score earned is 4.0 then the mean score is in the category of 'Very Good.' Fourthly, Benefit/Usability of the worksheet shows that the mean score earned is three then the mean score is categorized as 'Excellent'. More details were seen in Figure 2.

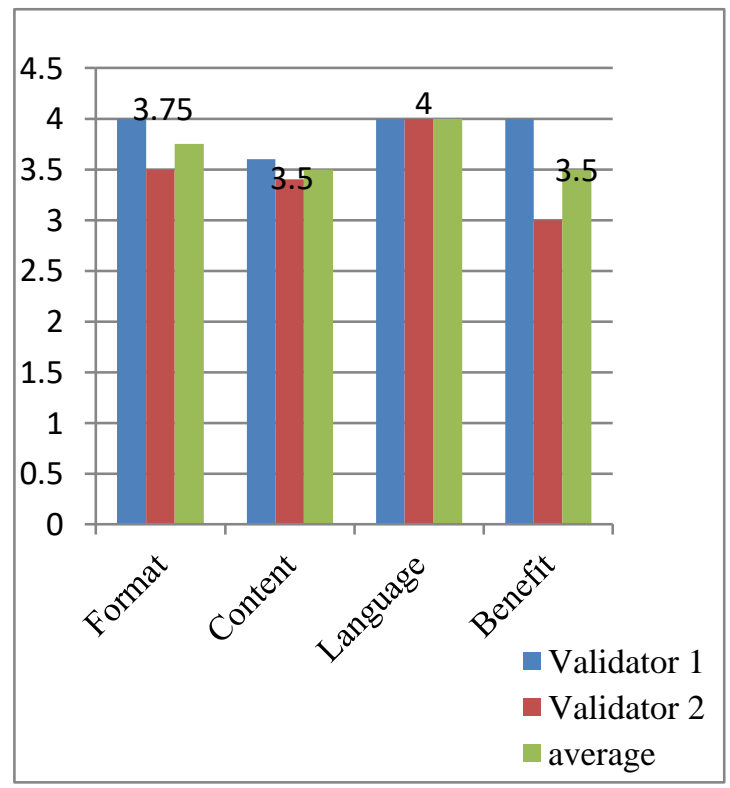

Figure 2. Experts' validation chart

The results of the scoring data obtained from the experts can show that the worksheet product belongs to the category of 'Very Good.' This proves that the experts averagely give a high assessment of the developed worksheet product. Therefore, it concluded that the development of student worksheets in SMA Muhammadiyah Al-Amin, Sorong, can be used for every trial conducted. This is consistent with research by (Alina et al., 2016) who explained that validation of the worksheet has an impact on the learning outcomes of the students in the classroom.

The result of the normality test of the

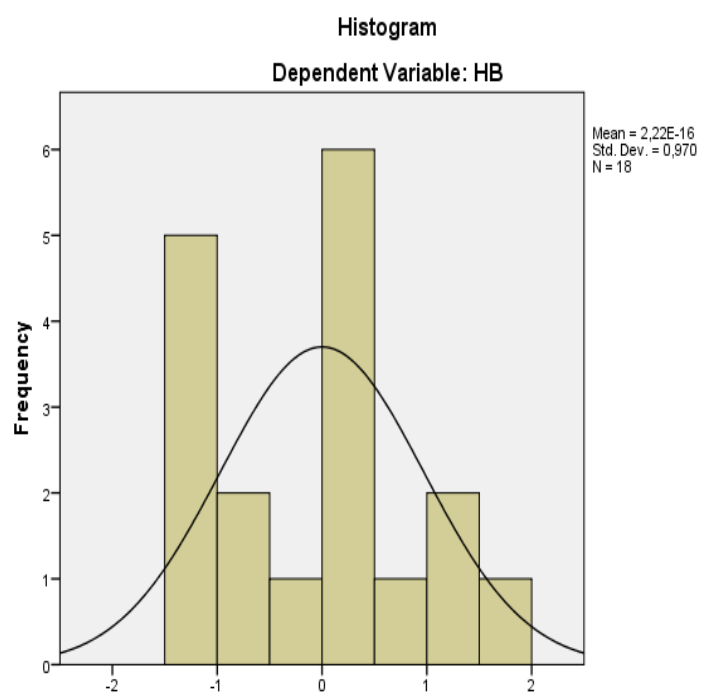

learners' outcomes seen in figure 3.

Figure 3. Normality test chart

The figure above shows that the results obtained by the learners when following the learning process have a normal distribution. Based on these data, the results of the descriptive analysis done show that the score obtained by the learners in following the learning on the Fluid subject showing the results of problem-solving is 79.44. This indicates that the learners, averagely, can understand the learning materials when a problem-solving-oriented learning process is implemented based on the process of practicum in the classroom and the laboratory.

This is also supported by another research by Seyhan (2015) that shows 
the students' problem-solving abilities are very dependent on the perception of the subject matter that has been learned. In addition, with the improvement of the ability, the students are able to be more active in honing their thinking skills caused by the application of good learning methods. The results of the descriptive analysis indicate that the scores of problem-solving of the learners are as shown in table 1.

Table 1. Descriptive analysis of the scores of problem-solving of the learners

\begin{tabular}{cc}
\hline Information & Result \\
\hline Number of Respondents & 18 \\
Mean & 79,44 \\
Median & 80,00 \\
Modus & 65,00 \\
Standard Deviation & 10,27 \\
Skewness & 0,12 \\
Minimum Score & 65,00 \\
Maximum Score & 95,00 \\
\hline
\end{tabular}

This analysis proves that the achievement of the results obtained by the learners during the learning of physics in the classroom experienced a significant improvement with the maximum score of 95 and the minimum score of 65 . The results of t-test done using one sample tests how that the score of $t_{\text {count }}=32.806$ $>t_{\text {table }}=1.734$ with the significance degree of 0.000 . Those show that the development of learners' worksheets affects improving problem-solving skills. The results obtained agree with (Sadipour et al., 2017) explaining that the oriented learning model of students' academic performance was able to provide better learning achievement, motivation, and problem-solving abilities.

In addition to the analysis mentioned above data, simple regression test results between students' learning outcomes and their responses in the next learning using worksheets can describe as well. This shown in Table 2.
Table 2. Correlation Test between Learning Outcomes to Student's Response

\begin{tabular}{cccc}
\hline & & Outcomes & Response \\
\hline Pearson & Outcome & 1,000 & 0,338 \\
Correlation & Response & 0,338 & 1,000 \\
Sig. & Outcome & - & 0,085 \\
(1-tailed) & Response & 0,085 & - \\
& Outcome & 18 & 18 \\
N & Response & 18 & 18 \\
\hline
\end{tabular}

From the table above, it can be seen that the score of learning achievement and the response of learners obtained have a significant correlation to the response of learners with Pearson correlation coefficient of 0.338 and significance level of 0.085 . These results indicate that the level of achievement of the development of problem solving-oriented learner's worksheet shows a significant improvement in the implementation. Similarly (Barniol \& Zavala, 2016) who explained that understanding to students could be improved through worksheets, to produce active learning. On the other hand (Stozhko et al., 2015) also suggests that project-based learning can develop students' problem-solving skills which are assisted by the use of learning media such as using worksheets, IT and so on.

Compared to other countries, such as Japan, the advantages in applying problem-solving learning by collaborating with various methods or approaches in implementing learning include: (1) students are more active and often express their ideas; (2) students have the opportunity to use their knowledge and skills extensively; (3) this method can give low-achievement students the opportunity to respond in their own way; (4) students are motivated to take lessons and (5) build a desire to find a problem (Asami-Johansson, 2015). In addition, the results of the study by Seyhan (2015) reveals that at the level of perception of problem-solving abilities, other process skills, and logical thinking abilities are more effective in compared to another 
conventional teaching methods. In addition, the learning outcomes obtained by students towards problem-solving abilities are quite significant.

On the other hand, these results prove that the response of learners has a significant relationship with their learning outcomes in which their ability to solve problems has increased. This is also supported by (Fhadhila, Ertikanto, \& Rosidin, 2018) which stated that the learner's worksheet effectively improves the average of the learning outcomes, in which the achievement of the development objectives is in the category of 'Good'. This is seen from the feedback given by the learners during the learning process with the results indicating a linkage to the effectiveness of the development of the worksheet.

Based on the results of the analysis of the data obtained, it found that the achievement of the learning process in the class got good results. This can be seen from the aspect of the device used. The achievement in question is to develop a valid, practical, and effective worksheet. To know the validity, each worksheet was assessed by two people. The results of the assessment of the two validators show that from the worksheet used in the developed learning, it was concluded that the worksheet is valid and practical.

The validity was illustrated by the results of the assessment of two validators where the developed learner's worksheet meets the criteria of validity with the average value of validity of 3.68 and is in the category of 'very valid.' This shows that from the aspect that was assessed and measured in the implementation of validation, it was seen that the learner's worksheet used is suitable for use in the learning process, so it was expected that this validation would have an impact on the improvement of learners' learning outcomes. In according to (Alina et al., 2016) the validity of worksheets provides a good response in the implementation of the learning process in the classroom.

The scores obtained indicate that the learners while following the lesson responded positively and were interested in the implementation of the learning process using problem solving-oriented worksheet in the classroom. Differences in the results obtained were due to the previous learning process different from the process of learning-oriented problem solving using the learner's worksheet, where each learner shows considerable interest in solving the problem. This is in line with research conducted by (Khairani \& Febrinal, 2016) which stated that testing the potential impact of the use of learning media can provide convenience to learners in understanding the lesson in the classroom.

The application of the oriented learning process enables the learners to be able to implement the results obtained and connect each learning material with daily life. In addition, it also describes the level of ability of learners in completing the problem-solving test, where the results of the testability of learners obtained on average are in the category of completeness, but the minimum score obtained learners fall into the category does not reach the minimum mastery criteria (KKM) which became the basis of the assessment of learning outcomes. There were just four students who can obtain that score. This indicates that there is still a small percentage of learners who still need special treatment in the learning process. In according to (Keller et al., 2017) stated that teachers must have pedagogic abilities in delivering material contextually to increase motivation and learning achievement.

Guidance and interest in the implementation of physics learning need to be encouraged again to improve their abilities. On the other hand, according to (Rahayu et al., 2017) the development of problem solving-oriented learning 
strategy using a worksheet can be a new model for learners in developing their thinking skills and honing other skills. This strategy encourages them to think more creatively. Therefore, learning based on problem-solving aspect and development of the learner's worksheet which is carried out by the process of practicum able to train learners to construct their knowledge and investigate a concept, as well as able to reflect the concept that was understood.

This is in line with the statement of (Puspitasari \& Munawi, 2018) which explained that the implementation of an approach, method, and model of learning could stimulate changes in the mindset of learners in solving the problem. Similarly (Lan, Hsiao, \& Shih, 2018) explained that the implementation of a design in learning-oriented towards the use of instructional media was able to provide meaningful learning for students. Furthermore (Kahar, 2017) also explained that the problem-solving ability could give impact to the students in their ability of mathematical thinking in solving problems in their everyday life.

In according to (Panaoura et al., 2017) explained that problem-oriented learning could improve student learning outcomes and can also help improve understanding of physical concepts. On the other hand (Diani, Yuberti \& Syarlisjiswan, 2018) explained that learning based on problembased learning could provide positive interaction for students so that the learning process carried out by students can run effectively, efficiently and be able to understand the material being taught. Another result of research (Amin \& Mahmud, 2016) also explains that the development of a learning media through visual media or worksheets were able to have a significant impact on improving students' problem-solving abilities which include concept map ability and mathematical abilities.

\section{CONCLUSION AND SUGGESTION}

Some conclusions can be made based on the results of the research: the development of problem-solving oriented student worksheets is declared valid and effective based on the results of validation by the experts and the results of the implementation of classroom learning.

Furthermore, in learning by using problem-solving oriented worksheets, it is obtained the average learning outcomes of 79.44 with the results of the analysis of $\mathrm{t}_{\text {count }}=32.806>\mathrm{t}_{\text {table }}=1.734$ with the significance degree of 0.000 . On the other hand, in the implementation of worksheets oriented to problem-solving shows the influence on students' responses to learning with a score of 0.338 with a significance level of 0.085 .

The implication by these results has an impact on improving student learning outcomes so that it was expected that learning process with different materials can be applied in improving students' ability to solve problems. It is expected that in the learning process with different materials, the worksheet can be applied in improving students' ability to solve problems. It is suggested for a research to collaborate the worksheet with other models and, media that can be linked to the problem-solving aspects, so that in its implementation, students have the confidence to succeed, be more active, and interested in problem-solving given.

\section{ACKNOWLEDGMENT}

Thanks to the Directorate of Research and Community Service and the Directorate General of Research and Development Reinforcement of the Ministry of Research, Technology and Higher Education who have provided funding assistance in 2018.

\section{REFERENCES}

Alina, Dining Nika; Purnomo, Tarzan; Kuntjoro, S. (2016). Validitas Lks Ekosistem Mangrove Berbasis Sets 
Pada Materi Ekosistem Untuk Sma Di Wilayah Pesisir Surabaya. Berkala Ilmiah Pendidikan Biologi, 5(3), 189-193.

Amin, B. D., \& Mahmud, A. (2016). The Development of Physics Learning Instrument Based on Hypermedia and Its Influence on the Student Problem Solving Skill. Journal of Education and Practice, 7(6), 22-28. Retrieved from http://libproxy.library.wmich.edu/log in?url=https://search.proquest.com/d ocview/1826527141 ?accountid=150 99

Asami-Johansson, Y. (2015). Designing Mathematics Lessons Using Japanese Problem Solving Oriented Lesson Structure: A Swedish case study. In Linkoping Universitet.

Barniol, P., \& Zavala, G. (2016). A tutorial worksheet to help students develop the ability to interpret the dot product as a projection. Eurasia Journal of Mathematics, Science and Technology Education, 12(9), 23872398.

https://doi.org/10.12973/eurasia.201 $6.1271 \mathrm{a}$

Ceberio, M., Manuel Almudi, J., \& Franco, A. (2016). Design and Application of Interactive Simulations in Problem-Solving in University-Level Physics Education. Journal of Science Education and Technology, 25(4), 590-609. https://doi.org/10.1007/s10956-0169615-7

Darma; I, K, Candiasa; I, M, Sadia; I, W, D. N. (2018). The effect of problembased learning model and an authentic assessment of mathematical problem-solving ability by using the numeric ability as the covariable The effect of problem-based learning model and an authentic assessment of mathematical problem-solving ability. Journal of Physics: Conf.
Series, 1040.

Diani, R., \& Syarlisjiswan, M. R. (2018). Web-Enhanced Course Based On Problem-Based Learning (PBL):

Development Of Interactive Learning Media For Basic Physics II. Jurnal Ilmiah Pendidikan Fisika AlBiruni, 07(April), 105-116. https://doi.org/10.24042/jipfalbiruni. v7i1.2849

English, L. D., Hudson, P., \& Dawes, L. (2013). Engineering-Based Problem Solving in the Middle School: Design and Construction with Simple Machines. Journal of PreCollege Engineering Education Research, 3(2), 43-55. https://doi.org/10.7771/21579288.1081

Fathurrahman, M; Ibrahim, Ibrahim; Kahar, M S; Arsyad, R; Rawi, R. D. P. (2018). Development of Learning Media Based on MOODLE Integrated with Blended Learning in Mathematics Learning Process at SMA Muhammadiyah Al - Amin Sorong. Development of Learning Media Based on MOODLE Integrated with Blended Learning in Mathematics Learning Proc. In IOP Conference Series: Earth and Environmental Science (pp. 1-6).

Fhadhila, F., Ertikanto, C., \& Rosidin, U. (2018). Developing Student Worksheet of Temperature and. Jurnal Ilmiah Pendidikan Fisika AlBiRuNi, 07(April), 21-32. https://doi.org/10.24042/jipfalbiruni. v7i1.2318

Firdaus, M., \& Wilujeng, I. (2018). Pengembangan LKPD Inkuiri Terbimbing Untuk Meningkatkan Keterampilan Berpikir Kritis dan Hasil Belajar Peserta Didik. Jurnal Inovasi Pendidkan IPA, 4(1), 26-40. https://doi.org/http://dx.doi.org/10.21 831/jipi.v4i1.5574 Copyright

Fitriah, E. (2013). Implementasi Model Creative Problem Solving Bervisi 
Sets Dalam Meningkatkan Keterampilan Proses Sains Dan Kreativitas Siswa Sma Berbasis Pesantren. Jurnal Scientiae Educatia, 2(2).

Kahar, M. S. (2017). Analisis Minat Belajar Mahasiswa Terhadap Penggunaan Alat Peraga Neraca Cavendish. SEJ (Science Education Journal), $1(2), \quad 73$. https://doi.org/10.21070/sej.v1i2.117 7

Kahar, M. S. (2018). Motivation Analysis Learning in The Implementation of Physics Practicum. Jurnal Ilmiah Pendidikan MIPA, 8(1), 1-6. Retrieved from http://journal.lppmunindra.ac.id/inde x.php/Formatif/article/view/2285/18 58

Kahar, M. S., Fathurrahman, M., Amri, I., \& Pristianto, H. (2018). Development of Cavendish Balance of Aids Based on Blender Application in Learning Physics Development of Cavendish Balance of Aids Based on Blender Application in Learning Physics. In IOP Conference Series: Earth and Environmental Science (pp. 1-5).

Keller, M. M., Neumann, K., \& Fischer, H. E. (2017). The impact of physics teachers' pedagogical content knowledge and motivation on students' achievement and interest. Journal of Research in Science Teaching, 54(5), 586-614. https://doi.org/10.1002/tea.21378

Kemp; Jerrold; E. (1995). Instruction Desigen: A Plan for Unit and Course Development. Belmont: Feron.

Khairani, Majidah; Febrinal, D. (2016). Pengembangan Media Pembelajaran Dalam Bentuk Macromedia Flash Materi Tabung Untuk Smp Kelas IX. Jurnal Ipteks Terapan Research of Applied Science and Education, 10(12), 95-102. https://doi.org/10.22216/jit.2016.v10 i2. 440

Lan, Y., Hsiao, I. Y. T., \& Shih, M. (2018). Effective Learning Design of Game-Based 3D Virtual Language Learning Environments for Special Education Students. Educational Technology \& Society, 21(3), 213227.

Noor, Muhammad; Zainuddin, \& Miriam, S. (2017). Pengembangan Perangkat Pembelajaran Ipa Fisika Melalui Model Pengajaran Langsung Dengan Metode Problem Solving. Berkala Ilmiah Pendidikan Fisika, 5(3), 328339.

Panaoura, A., Michael-Chrysanthou, P., Gagatsis, A., Elia, I., \& Philippou, A. (2017). A Structural Model Related to the Understanding of the Concept of Function: Definition and ProblemSolving. International Journal of Science and Mathematics Education, 15(4), 723-740. https://doi.org/10.1007/s10763-0169714-1

Powell, L. E., Wild, M. R., Glang, A., Ibarra, S., Gau, J. M., Perez, A., ... Slocumb, J. (2017). The development and evaluation of a web-based programme to support problem-solving skills following brain injury. Disability and Rehabilitation: Assistive Technology. https://doi.org/10.1080/17483107.20 17.1389999

Purnamawati, D., Ertikanto, C., \& Suyatna, A. (2017). Keefektifan Lembar Kerja Siswa Berbasis Inkuiri untuk Menumbuhkan Keterampilan Berpikir Tingkat Tinggi. Jurnal Ilmiah Pendidikan Fisika Al-Biruni, 6(2), 209. https://doi.org/10.24042/jipfalbiruni. v6i2.2070

Puspitasari, M. D. M., \& Munawi, H. A. (2018). Perubahan Pola Berpikir Mahasiswa Pada Fenomena Perpindahan Panas Secara Konveksi. 
Berkala Ilmiah Pendidikan Fisika, 6(2), 142. https://doi.org/10.20527/bipf.v6i2.49 09

Putri, Sri Diana, Djamas, D. (2017). Pengembangan

Perangkat Pembelajaran Fisika Berbasis Keterampilan Berpikir Kritis dalam Problem-Based Learning. Jurnal Ilmiah Pendidikan Fisika Al-Biruni, 6(1), 125. https://doi.org/10.24042/jpifalbiruni. v6i1.648

Rahayu, T., Syafril, S., Wati, W., \& Yuberti, Y. (2017). The Application of STAD- Cooperative Learning in Developing Integrated Science on Students Worksheet. Jurnal Ilmiah Pendidikan Fisika Al-Biruni, 6(2), 247.

https://doi.org/10.24042/jipfalbiruni. v6i2.1933

Sadipour, I., Ghavam, S. E., Farrokhi, N., \& Sameti, N. (2017). A Model to Predict Academic Performance based on the Components of Emotional Intelligence, Problem Solving Skills and Achievement Motivation among Students of Smart and Ordinary School. International Journal of Environmental \& Science Education, 12(5), 1353-1369.

Schoenfeld, A. H. (2016). Learning to Think Mathematically: Problem
Solving, Metacognition, and Sense Making in Mathematics (Reprint). Journal of Education, 196(2), 1-38. https://doi.org/10.1177/00220574161 9600202

Seyhan, H. G. (2015). The effects of problem-solving applications on the development of science process skills, logical thinking skills and perception on problem-solving ability in the science laboratory. Asia-Pacific Forum on Science Learning and Teaching, 16(2), 1-31.

Stozhkosny@usue.ru, N., Bortnik, B., Mironova, L., Tchernysheva, A., \& Podshivalova, E. (2015). Interdisciplinary project-based learning: technology for improving student cognition. Research in Learning Technology, 23(1063519), $1-13$.

https://doi.org/10.3402/rlt.v23.27577

Suharsimi, A. (2006). Dasar-Dasar Evaluasi Pendidikan. In Jakarta: Bumi Aksara (p. 168).

Tanti, T., Jamaluddin, J., \& Syefrinando, B. (2017). Pengaruh Pembelajaran Berbasis Masalah terhadap Beliefs Siswa tentang Fisika dan Pembelajaran Fisika. Jurnal Ilmiah Pendidikan Fisika Al-Biruni, 6(1), 23.

https://doi.org/10.24042/jpifalbiruni. v6i1.603 